\title{
Novel margin management to enhance Auchenorrhyncha biodiversity in intensive grasslands
}

Article

Accepted Version

Blake, R.J., Woodcock, B.A., Ramsay, A.J., Pilgrim, E.S., Brown, V.K., Tallowin, J.R. and Potts, S. (2011) Novel margin management to enhance Auchenorrhyncha biodiversity in intensive grasslands. Agriculture Ecosystems \& Environment, 140 (3-4). pp. 506-513. ISSN 0167-8809 doi:

https://doi.org/10.1016/j.agee.2011.02.003 Available at https://centaur.reading.ac.uk/24733/

It is advisable to refer to the publisher's version if you intend to cite from the work. See Guidance on citing.

To link to this article DOI: http://dx.doi.org/10.1016/j.agee.2011.02.003

Publisher: Elsevier

All outputs in CentAUR are protected by Intellectual Property Rights law, including copyright law. Copyright and IPR is retained by the creators or other copyright holders. Terms and conditions for use of this material are defined in the End User Agreement. 


\section{CentAUR}

Central Archive at the University of Reading

Reading's research outputs online 


\section{Novel margin management to enhance Auchenorrhyncha}

\section{biodiversity in intensive grasslands}

R. J. Blake1, B. A. Woodcock ${ }^{2}$, A. J. Ramsay ${ }^{3}$, E. S. Pilgrim ${ }^{4}$, V. K. Brown ${ }^{1}$, J. R. Tallowin ${ }^{4}$ and S. G. Potts ${ }^{1}$

${ }^{1}$ Centre for Agri-Environmental Research, School of Agriculture, Policy and Development, University of Reading, Reading, RG6 6AR, UK.

${ }^{2}$ NERC Centre for Ecology \& Hydrology, Crowmarsh Gifford, Wallingford, Oxon OX10 8BB, UK.

${ }^{3}$ Thomson Ecology, Calls Wharf, 2 The Calls, Leeds, LS2 7JU, UK.

${ }^{4}$ Rothamsted Research, North Wyke, Okehampton, Devon, EX20 2SB, UK.

Running title: Enhancing Auchenorrhyncha in intensive grasslands

Corresponding Author

Robin Blake. E-mail: r.blake@reading.ac.uk; Tel. +44(0)118 378 4397. Centre for AgriEnvironmental Research, School of Agriculture, Policy and Development, University of Reading, Reading, UK, RG6 6AR. 


\begin{abstract}
Agricultural intensification, including changes in cutting, grazing and fertilizer regimes, has led to declines in UK and NW European grassland biodiversity. We aimed to develop field margin management practices that would support invertebrate diversity and abundance on intensively managed grassland farms, focusing on planthoppers and leafhoppers (Auchenorrhyncha). Replicated across four farms in south-west England, we manipulated conventional management practices (inorganic fertilizer, cutting frequency and height, and aftermath grazing) to create seven treatments along a gradient of decreasing management intensity and increasing sward architectural complexity. Auchenorrhyncha were sampled annually between 2003 and 2005. Auchenorrhyncha abundance and species richness was highest in the most extensively-managed treatments. Abundance was lowest with frequent cutting, while species richness was lowest where cattle grazing occurred. Unexpectedly, application of inorganic fertilizer had no effect on Auchenorrhyncha abundance or species richness. Management options that enhance invertebrate diversity, while allowing the remainder of the field to be managed conventionally, represent a potentially important conservation tool for many lowland improved grasslands. Extensification of conventional management in field margin areas of such grasslands are likely to benefit this numerically dominant component of grassland invertebrate fauna. These management practices have the potential to be incorporated into existing UK and European agri-environment schemes.
\end{abstract}

Keywords: Field margins; Architecture; Planthoppers; Leafhoppers. 


\section{Introduction}

Permanent ( $>5$ years old) and temporary ( $<5$ years old) grassland exceeds 7.3 million hectares in the UK, an area equivalent to approximately $40 \%$ of all agricultural land (Defra, 2010a). Despite its land coverage, the quality and biodiversity value of this grassland has deteriorated during the latter part of the twentieth century, resulting in population declines of plants (e.g. Green, 1990), invertebrates (e.g. Duffey et al., 1974) and birds (e.g. O'Connor and Shrubb, 1986). These declines are widely attributed to modern intensive grassland management practices that have been developed to maximise the production of livestock (e.g. Fuller, 1987; Frame, 2002; Marren, 2002). These include the fertilisation and reseeding of traditional meadows with one or two high-yielding species, such as Lolium perenne L. (Poaceae) and Trifolium repens L. (Fabaceae) (Fuller, 1987). Technological advances in silage production have also led to increased cutting frequencies and earlier first cuts (Marren, 2002), that have resulted in a reduction in floral resources for insect pollinators and seed eating birds (Vickery et al., 2001). High stocking densities and the increased frequency of cutting have both simplified and homogenised sward architecture (Green, 1990; Vickery et al., 2001). The result of these management practices has been the creation of grassland swards of low conservation value for invertebrates, plants and birds (Atkinson et al., 2005; Tallowin et al., 2005; Woodcock et al., 2007a).

As suggested above, an important determinant of invertebrate diversity in grasslands is sward architectural complexity (Lawton, 1983; Vickery et al., 2001; Woodcock et al., 2005). This is defined as the complexity of the above-ground vegetation structures (Lawton, 1983). Sward architectural complexity is the product of morphological and phenological differences between plant species, and is influenced by botanical composition and the frequency and type of management practices (e.g. Duffey et al., 1974; Morris, 2000). For 
many phytophagous invertebrates there is a high degree of specificity in terms of what plant structures they feed upon (e.g. roots, leaves, seed pods and inflorescences), even when they share a common host plant (Morris, 2000). Management practices that change sward architectural complexity and thus the occurrence of these structures will therefore impact upon the abundance and species richness of many invertebrates (Gibson et al., 1992; Woodcock et al., 2005). Different invertebrate guilds respond to different components of sward architecture (Woodcock et al., 2005). For example, some species of Auchenorrhyncha (planthoppers and leafhoppers) benefit from structurally simple short swards, while the majority are negatively affected by cutting and grazing regimes (Morris, 1971, 1973). Negative impacts of cutting and grazing mediated through changes in sward architecture can also affect predatory invertebrates, such as spiders (Gibson et al., 1992; Baines et al., 1998).

Within the UK, the management of non-cropped field margins to promote native biodiversity has been widely used in the context of arable farming systems as a product of agri-environmental schemes (e.g. Meek et al., 2002; Asteraki et al., 2004). However, in the context of improved grassland systems, options for extensively-managed field margins are considerably reduced. The most widely used are typically 2-6 metre buffer strips (Options EE4-6 of the UK Entry Level Stewardship schemes) which have no fertilizer inputs, and restricted cutting regimes (Defra, 2010b). By 'extensively-managed' we refer to a decrease in management intensity. While several studies have shown their potential value for plants (Sheridan et al., 2008), pollinators (Potts et al., 2009), and predatory invertebrates (Woodcock et al., 2007a; Woodcock et al., 2009), uptake has been low (Defra, 2009) and therefore their wider environmental value is currently limited.

Here, we investigate how extensification of management in field margin areas of agriculturally improved grasslands can be used to promote Auchenorrhyncha abundance and diversity. Auchenorrhyncha are an abundant component of grassland systems and have 
considerable functional importance (Biedermann et al., 2005), both as herbivores and as prey, for higher trophic levels (Nickel and Hildebrandt, 2003). Auchenorrhyncha have also been shown to be good indicators of the ecological health of grasslands, due to their strong and rapid responses to management practices, reflecting their rapid generation times (Morris, 2000; Nickel and Hildebrandt, 2003; Biedermann et al., 2005). Auchenorrhyncha have diverse life strategies, ranging from specialist monophagous species feeding on a single plant species, to generalist polyphagous species with host plants represented across multiple plant families (Nickel and Hildebrandt, 2003). Auchenorrhyncha may also be uni-, bi- or multivoltine (i.e. capable of 1, 2 or > 2 generations per year respectively) (Nickel and Hildebrandt, 2003). This study investigates the impact on Auchenorrhyncha populations of a suite of grassland management practices, including the height and timing of sward cuts, cattle grazing and inorganic fertilizer (NPK) inputs. We make the following predictions: 1) Auchenorrhyncha abundance and species richness will increase as management intensity is reduced within improved grassland field margins; 2) Specialist Auchenorrhyncha will be more sensitive to intensive grassland management than generalist species; 3) Management that decreases sward architecture will have a direct negative impact on both the abundance and species richness of Auchenorrhyncha. Although this study focuses on field margins, the findings will have direct relevance to the management of lowland grassland systems in general.

\section{Materials and Methods}

\subsection{Study Sites}

The study was replicated on four lowland farms in the UK, two in Somerset

(Bickenhall, N50'58'47':W2'59'29"; and South Hill, N5057'40":W302'53") and two in 
Devon (Heywoods, N5048'38":W355'40"; and North Wyke N5046'14":W355'46"). All farms had a predominance of improved grasslands that were classified as species-poor $L$. perenne leys. Prior to study initiation, the swards contained the grasses Agrostis capillaris L. (Poaceae) and Holcus lanatus L. (Poaceae), as well as the forbs T. repens and Ranunculus repens L. (Ranunculaceae). All experimental plots were established on permanent pastures (i.e. > 5 years old). The Bickenhall and South Hill farms were located on lime-rich, loamy and clayey soils, with impeded drainage. The Heywoods and North Wyke farms were located on slowly permeable, seasonally wet, acid loamy and clayey soils. The fields adjacent to the experimentally manipulated margins were conventionally managed with multiple silage cuts, inorganic fertilizer and aftermath grazing. Individual farms were separated from their nearest neighbour site by at least eight kilometres.

\subsection{Experimental Design}

Randomised block designs of seven field margin management treatments were established in spring 2003 on each farm and were monitored annually from 2003 to 2005 . Experimental plots measured $50 \mathrm{~m} \times 10 \mathrm{~m}$ with the long edge running parallel to the hedgerow field boundary. Three replicates of each treatment were established at each of the four farms, giving 12 replicate blocks in total. Treatments were randomly allocated within blocks, although an individual block was sometimes split between more than one field. This was a practical necessity, as individual field sizes were often small.

The seven treatments within each block followed an extensification gradient intended to create a sequential increase in sward architectural complexity. All management treatments represented combinations of grazing by cattle (present or absent), cutting for silage (cut at one of two heights $(5$ or $10 \mathrm{~cm}$ ) in May and / or July) and the application of inorganic 
fertilizer (Table 1). All management manipulated the existing swards, i.e. these seven treatments were not reseeded. Treatment 1 was the control, representing conventional intensive grassland management, and received inorganic fertilizer at rates of $225 \mathrm{~kg} \mathrm{ha}^{-1}$ nitrogen $(\mathrm{N}), 22 \mathrm{~kg} \mathrm{ha}^{-1}$ phosphorus $(\mathrm{P})$ and $55 \mathrm{~kg} \mathrm{ha}^{-1}$ potassium $(\mathrm{K})$, two cuts to $5 \mathrm{~cm}$ in May and July, and aftermath grazing. Treatments 1-3 were grazed by cattle in September to a target height of 5-7 cm. Treatments 3 and 4 received inorganic fertilizers at the same rates as the control. Treatments 5-7 were extensively managed and investigated the effects of temporal variation on cutting dates, with either a single silage cut in May (treatment 5), or hay cut in July (treatment 6), or unmanaged (treatment 7). Further detail on the management of these margins can be found in Woodcock et al. (2007a).

\subsection{Vegetation Sampling}

During August of each year, percentage cover of all vascular plant species, dead vegetation, and bare ground, was estimated by vertical projection within fixed $1 \times 1 \mathrm{~m}$ quadrats placed at equal distances along a diagonal transect within each plot. This timing was chosen to allow sufficient time for the sward to recover following the second cut, and was prior to the aftermath grazing.

Following the methods described by Woodcock et al. (2007a) fine grain sward architectural complexity was measured using vertical drop pins. In summary, $10 \times 3$-mm diameter pins (separated by $1 \mathrm{~cm}$ ) were lowered vertically through the sward of each plot and the number of vegetation contacts of each species was recorded at $5 \mathrm{~cm}$ intervals going up these pins. This provided stratified information on the vertical distribution of plant structures, referred to here as sward architecture. A modified version of the Shannon-Wiener 
diversity index was used to summarize information from the drop-pin frames into a single parameter:

$H^{\prime}{ }_{\text {arch }}=\sum p_{i} \times \log _{\mathrm{e}} p_{i}$

where $H_{\text {arch }}^{\prime}$ is the index of sward architectural complexity and $p_{i}$ the proportion of the total number of contacts with the drop pin in a particular plot at each height interval $i$. Sward architecture was measured four times each year, corresponding with the Auchenorrhyncha sampling dates, although an average measure of sward architecture was used in subsequent analyses.

\subsection{Invertebrate sampling}

Auchenorrhyncha were collected four times a year (April, June, July and September) from 2003-2005 using a Vortis suction sampler (Burkard Co. Ltd, Rickmansworth, UK). Suction sampling is an established method for the collection of quantitative data on aboveground grassland invertebrates (Woodcock et al., 2007b; Brook et al., 2008). Sampling was conducted between 10:00 and 16:00 $\mathrm{h}$ when the weather was dry. Both the June and September sampling rounds occurred at least two weeks after sward cutting management. In each plot, $75 \times 10$ second suctions $(0.26 \%$ of the plot area) were made. This number has been shown to be adequate to ensure sampling of at least $90 \%$ of the total abundance and species richness of the Auchenorrhyncha (Brook et al., 2008). Samples were evenly spaced out along the experimental plot. For a given year all suction samples were pooled for each individual experimental plot.

Adult Auchenorrhyncha were identified to species and assigned to one of the three feeding specialisations proposed by Nickel and Remane (2002). These were: 1) monophagous (i.e. species feeding on only 1 plant species or 1 plant genus); 2) oligophagous 
species feeding on 1-5 plant families; 3) polyphagous species feeding on > 5 plant families. In this paper, the term 'Auchenorrhyncha' includes the infraorders Fulgoromorpha and Cicadomorpha.

\subsection{Data Analysis}

Auchenorrhyncha abundance, plant species richness, and sward architecture were averaged across the three blocks of each treatment within a site, giving for each response and explanatory variable four replicates of each treatment (one for each farm) in all subsequent analyses. This was intended to reduce the impacts of within site variation associated with the fact that individual blocks were often split across multiple fields within a farm. Repeatedmeasures analysis using general linear mixed models in SAS 9.2 (SAS, 2008), were used to analyse the response of Auchenorrhyncha abundance and species richness to treatment effects and continuous and categorical environmental variables. Response variables were the abundance $\left(\log _{\mathrm{e}} n+1\right)$ and species richness $\left(\log _{\mathrm{e}} n+1\right)$ of total Auchenorrhyncha (i.e. all feeding specialisations), as well as separately for monophagous, oligophagous and polyphagous species. The analysis was divided into three separate models, dealing with overall treatment effects (representing combinations of multiple management practices), management effects and continuous measures of the plant community.

Model 1 tested for treatment effects, where each treatment represented a combination of different management practices (i.e. cutting, grazing and fertilizer) and is defined by a management extensification gradient from treatments 1 to 7 . This model included the fixed effects of explanatory variables of year, treatment and the treatment $\times$ year interaction.

Model 2 tested for specific responses of the Auchenorrhyncha to individual management practices and included the explanatory variables year, categorical environmental 
variables that code for specific management practices, as well as their interaction with year. The categorical environmental variables were: (i) presence or absence of grazing (Grazed); (ii) number of silage cuts ( 0,1 or 2 cuts per year) (Cutting no.); and (iii) presence or absence of NPK fertilizer application ( $\mathrm{N}$ treat). Note that for model 2 the management treatments are confounded to some extent by the existence of other management practices applied to the same plot. However, in the context of real grassland systems it would be rare for management practices to be applied in isolation, while identification of the importance of individual management practices for Auchenorrhyncha will help elucidate the mechanisms underpinning responses seen to the extensification gradient described in Model 1.

Model 3 considers the effect of continuous descriptors of the plant community on the Auchenorrhyncha. As management will directly influence these continuous model parameters (e.g. sward architecture will by definition be influenced by cutting), these explanatory variables could not be included in either Model 1 or 2 . Model 3 tested the effect of year, the continuous environmental variables and their interaction with year. The continuous environmental variables were: (i) sward architecture (Sward); (ii) grass species richness (Grass); and (iii) forb species richness (Forb).

Model 4 tested for the response of sward architecture to treatment effects, where each treatment represented a combination of different management practices and is defined by a management extensification gradient from treatments 1 to 7 . This model included the fixed effects of explanatory variables of year, treatment and the treatment $\times$ year interaction.

All models used an autoregressive covariance structure to account for increased similarity between repeated measures in subsequent sampling years. Site (i.e. farm) was used as a random effect. Solutions for both fixed explanatory and random effects were estimated using the residual maximum likelihood approach, with denominator degrees of freedom calculated using Kenward Rogers approximation. Model simplification was by stepwise 
elimination of the least significant term until the most parsimonious model was achieved. Significance values were derived from F-ratios of fixed effects, calculated using adjusted sums of squares where the final minimum adequate model contained only those parameters that had significant F-values, or were part of significant interaction terms. Between-treatment differences in response variables were tested using post hoc Tukey's multiple comparison test $(P=0.05)$

\section{Results}

Over the three experimental years, 48,099 Auchenorrhyncha were identified to one of 48 species, of which seven species were represented by only a single individual (Appendix A, Supplementary Data). The infraorder Fulgoromorpha comprised 11 species in two families (Cixiidae and Delphacidae), and the Cicadomorpha comprised 37 species in two families (Cercopidae and Cicadellidae). The species were categorised according to their feeding specialisations (monophagous: 3,760 individuals, 12 species; oligophagous: 32,994 individuals, 22 species; and polyphagous: 11,345 individuals, 14 species). There were 25 grass species (Poaceae) and 76 forb species recorded, of which the three most common families were Asteraceae (17 species), Fabaceae (10 species), and Polygonaceae (8 species).

\subsection{Response of Auchenorrhyncha to extensification}

There was a general trend of increasing Auchenorrhyncha abundance and species richness from treatment 1 to 7 , i.e. following the management extensification gradient (Figs. 1a \& b; Table 2). Tukey's test revealed a significantly higher abundance of total 
Auchenorrhyncha (i.e. all feeding specialisations) in treatments 5-7 compared with treatment $1(P<0.05)$. Similarly, there was a significantly higher abundance of oligophagous Auchenorrhyncha in treatments 5 and 7 compared with treatment 1, and of monophagous and polyphagous Auchenorrhyncha in treatment 7 compared with 1 only $(P<0.05)$ (Fig. 1a). Significantly higher values were observed in treatment 7 for total species richness and treatment 6 for oligophagous species richness, compared with treatment $1(P<0.05)$ (Fig. 1b). There were no significant differences between treatments for monophagous and polyphagous species richness. There were no other significant fixed effects of interaction terms for any of the response variables.

\subsection{Response of Auchenorrhyncha to management}

Model 2 described the effects on the Auchenorrhyncha of the categorical factors (Table 2). Auchenorrhyncha abundance across all groups (total, monophagous, oligophagous and polyphagous) responded to the frequency of sward cuts. Tukey's test revealed a trend of decreasing abundance with increasing cutting frequency for both the total and oligophagous groups $(0>1>2$ cuts) $(P<0.05)$ (Fig. $2 \mathrm{a})$. Two cuts produced a significantly lower abundance of polyphagous species compared to zero or one cut $(P<0.05)$. A single cut produced a significantly lower abundance of monophagous species than zero or two cuts $(P<$ 0.05). A significant effect of cut frequency was also observed for monophagous species richness $(P<0.05)$. There was also a weak interaction between fertilizer addition $(\mathrm{N}$ treat) and year for oligophagous species abundance $(P<0.05)$, with significant differences observed between all treatment years. Significant effects of grazing on Auchenorrhyncha species richness were observed for the total, monophagous and oligophagous groups. Tukey's test revealed significantly greater species richness for all three groups in the absence 
of grazing $(P<0.05)$ (Fig. 2b). There were no other significant fixed effects of interaction terms for any of the response variables.

\subsection{Response of Auchenorrhyncha plant community structure}

Model 3 investigated the responses of the Auchenorrhyncha to the continuous measures of plant community structure (Table 3). Abundance of oligophagous Auchenorrhyncha, and species richness of total and polyphagous species, was correlated with forb species richness, whilst monophagous abundance and species richness was correlated with grass species richness. However, the direction of these correlations showed a high degree of variability, changing from positive to negative between separate sample years. By contrast, oligophagous species richness was positively correlated with sward architecture for all three years of the study.

\subsection{Response of sward architecture to extensification}

There was a general trend of increasing sward architecture from treatment 1 to 7 , i.e. following the management extensification gradient (Fig. 3), with significant treatment $\left(\mathrm{F}_{6,17.9}\right.$ $=21.60, P<0.001)$ and year $\left(\mathrm{F}_{2,37.6}=33.73, P<0.001\right)$ effects. Tukey's test revealed significantly higher sward architecture values in treatments 5-7, compared with treatments 1 and $2(P<0.05)$. In addition, there was a weak interaction between treatment and year $\left(\mathrm{F}_{12,37.6}=2.12, P<0.05\right)$.

\section{Discussion}


In support of Prediction 1, Auchenorrhyncha abundance and species richness generally increased along the management extensification gradient defined by the seven main treatments. In all cases these represented a progressive reduction in cutting frequency and/or intensity, cessation of fertilizer input and cessation of grazing in late summer. This increase in abundance and species richness was most noticeable for those treatments that were either unmanaged (treatment 7), or received a single silage cut in May (treatment 5) or hay cut in July (treatment 6). The results support other studies that have shown higher abundance and species richness of beetles (Woodcock et al., 2007a) and insect pollinators (Potts et al., 2009) associated with extensively managed grassland field margins that receive no inorganic fertilizer or grazing management. Although effects of sample year were found, there were no significant year and treatment interactions, suggesting high between-year natural variation which can be a characteristic of Auchenorrhyncha populations (Prestidge, 1982). As expected, sward architectural complexity increased along the management extensification gradient, with the highest values observed in the most extensively managed treatments (i.e. 57).

Prediction 2 suggested that specialist Auchenorrhyncha would be more sensitive to intensive grassland management than generalist species. Nickel and Hildebrandt (2003) observed that generalist species dominated in high intensity treatments (i.e. $\geq 2$ cuts, grazed and fertilised) of German flood plain grasslands, with specialist species preferring low intensity management treatments that were unfertilised and mown only once per year. In our study, the observed responses were broadly similar across the feeding specialisations and management treatments. Significant responses of grass species richness on monophagous and polyphagous species richness highlighted the importance of grasses as host plants for both groups. Although Nickel and Remane (2002) showed that monophagous species were 
associated with grasses, sedges and rushes, the majority of monophagous species in our study were grass feeders. Similarly, whilst polyphagous species can feed on forbs (Nickel and Remane, 2002), Nickel et al. (2002) concluded that forbs only played a minor role as food plants. This dominance of the grasses within the sward confirms that grasses likely underpin population changes within improved grassland systems, at least in terms of our study area, i.e. South-West England.

Although oligophagous species richness did not respond to the grass or forb species richness, it was positively correlated with increasing sward architectural complexity for all three years of the study, and therefore would have been affected by the loss of sward architecture that occurs under more intensive cutting and grazing management regimes. Woodcock et al. (2007b) emphasised the importance of sward architecture for phytophagous invertebrates, and suggested that the presence of suitable host plants alone may be insufficient to allow successful establishment. Specifically, while many phytophagous species may utilise the same plant species, specialisation on different plant structures means that the effects of management on identical plant communities could have dramatically different impacts on the invertebrate community present. This explanation is particularly likely if different plant structures (roots, leaves, stems, inflorescences) differ in their likelihood of occurrence in response to sward management, e.g. inflorescences are likely to be lost by cutting.

Clear responses of Auchenorrhyncha abundance and species richness were observed to cutting and grazing. Both cutting and grazing had a deleterious effect on Auchenorrhyncha, with a general trend of decreasing abundance and species richness with increasing management intensity. Abundance was linked to the number of grass cuts, with a trend of decreasing abundance for all feeding groups with increasing cutting frequency. These results support studies that have shown direct mortality to Auchenorrhyncha (Morris, 
1981) and other invertebrates (Humbert et al., 2009) following cutting. This trend was particularly apparent for the responses of total and oligophagous species, where there was a higher abundance in the absence of cutting, and with a single compared to two cuts. These observations highlight the importance of frequency of cutting for Auchenorrhyncha populations and support a study by Nickel and Achtziger (2005) who observed a lower abundance and species richness with two cuts compared to a single cut. The timing of cutting is equally crucial, as Morris (1981) demonstrated that cutting twice per year in May and July (similar to treatments 1-4 in our study) was more deleterious for Auchenorrhyncha abundance than a single cut in May (our treatment 5). The July cutting date probably coincided with the peak summer abundance of adult Auchenorrhyncha (Biedermann et al., 2005), and so is likely to select against the populations by removing food, shelter, and oviposition opportunities (Nickel and Achtziger, 2005). Morris and Lakhani (1979) showed that the effect of mowing on abundance and species richness was comparatively short-lived on recently established grasslands, which are typically characterised by a high proportion of biand multivoltine species (i.e. capable of 2 or more generations per year respectively). In our study, the species were either uni-, uni- to bi-, or bivoltine (i.e. capable of 1, 1-2, or 2 generations per year respectively) (Appendix A, Supplementary Data). Although these generation characteristics were taken from a study conducted in Germany (i.e. Nickel and Remane, 2002), they were considered applicable to our study area, as both countries represent temperate regions of NW Europe and are therefore likely to have similar climatic conditions. Taking those species that were true univoltine (i.e. capable of only 1 generation per year) or true bivoltine (i.e. capable of two generations per year), the abundance of bivoltine species greatly outnumbered the univoltine species across all years of the study. According to Nickel and Hildebrandt (2003), generalist Auchenorrhyncha tend to be at least bivoltine, and specialist species are generally uni- or bivoltine. Our study provides further evidence that 
generalist species, by their bivoltine nature, are better able to adapt to intensive management practices and compensate for losses later in the season (e.g. from the July cut) than specialist species. Studies on other invertebrates have generally found reductions in both abundance and species richness following cutting (Morris, 2000). For example, Morris and Rispin (1987), found fewer predatory beetles in cut compared to uncut control plots.

Grazing offers a more selective management of the sward, and can help retain key topographical features such as tussocks that may be destroyed by cutting (Dennis et al., 1998). In our study, grazing by cattle was applied to treatments 1-3 in September each year to reduce the sward to a target height of 5-7 cm. Auchenorrhyncha species richness was linked to the presence or absence of grazing for the total, monophagous and oligophagous feeding groups, with lower species richness in grazed treatments (1-3) compared to the ungrazed (4-7). Our results support studies by Morris (1971) and Nickel and Hildebrandt (2003) who observed a higher Auchenorrhyncha species richness on ungrazed plots compared to plots grazed by sheep and cattle respectively. Furthermore, species which preferred tall grassland were less abundant in sheep-grazed plots compared to ungrazed plots (Morris, 1973). Grazing is often preferred by conservationists to cutting as it is more selective as not all plants are defoliated to the same degree (Morris, 2000). This is particularly true in the case of cattle, which are generally preferred to sheep as they tend to be less selective when choosing particular plant species, and can thus help maintain plant species diversity (Duffey et al., 1974). In addition, other behaviour of sheep and cattle, including trampling, dung production and the avoidance of less palatable plants, can also result in the enhancement of plant species diversity and architecture (Morris, 2000; Helden et al., 2010). Although differences exist between the grazing patterns of cattle and sheep (Duffey et al., 1974), the responses between the two animals in the context of the management applied in this study are expected to be similar, as the swards were grazed at a low intensity for only a 
few weeks of the year. As with cutting, grazing tends to lead to reductions in abundance and species richness of other phytophagous invertebrate groups (Morris, 2000; Sheridan et al., 2008), such as leaf miners (Brown et al., 1990). As the majority of UK grasslands are plagioclimax communities, they require appropriate management to prevent succession into scrub or woodland (Biedermann et al., 2005). While cessation of grazing and cutting may benefit Auchenorrhyncha species richness and abundance in the short-term (Morris, 1990), the absence of this management will eventually lead to species declines for plants and ultimately Auchenorrhyncha (Biedermann et al., 2005). In our study, the lowest intensity management regimes favoured the Auchenorrhyncha populations; however infrequent and rotational management such as cutting or grazing, is recommended to prevent scrub succession.

The application of inorganic fertilizer (NPK) to grasslands is intended to increase plant productivity and influence the botanical composition to favour more productive and palatable species (Frame, 2002). In our study, there was no difference in Auchenorrhyncha abundance and species richness between the fertilised treatments (1,3 and 4) and unfertilised treatments $(2,5-7)$ for the total, monophagous and polyphagous feeding groups. Previous studies have observed mixed responses for Auchenorrhyncha populations following fertilizer application. While Sedlacek et al. (1988) observed increases in Auchenorrhyncha abundance following fertilizer application, Andrzejewska (1976) and Prestidge (1982) found no significant reductions in species richness. Prestidge (1982) concluded that effects of fertilizer application are often extremely difficult to detect, as we have found, unless studies are conducted at species level and timed to coincide with the management application period. Our results may imply an interaction with other management practices as all the fertilised treatments, and the unfertilised treatments 2, 5 and 6, were managed in conjunction with 
cutting and/ or grazing. However, it was not possible to test the interactions between the management treatments in our study.

\section{Conclusions}

Despite the introduction of agri-environment schemes, agricultural grassland biodiversity continues to decline (Tallowin et al., 2005). There is a clear need to resolve the conflicting requirements of agricultural production and biodiversity conservation in livestock farms. This study has demonstrated that current grassland practices can be utilised to manage field margins for the benefit of Auchenorrhyncha populations. However, there is a need to maintain a balance if conservation strategies are to be successful. Grasslands require management to prevent succession into shrub and tree dominated habitats (Biedermann et al., 2005), and a single annual cut is a good way of achieving this, though this will have a shortterm impact on the predominantly bivoltine Auchenorrhyncha. However, the timing of the cut is likely to influence other aspects of farmland biodiversity. For example, while a May cut could benefit pollinating insects by promoting flower re-growth later in the summer (Potts et al., 2009), it might be detrimental to higher trophic levels, such as un-fledged groundnesting birds (Atkinson et al., 2005). A possible solution to meet the needs of a range of taxa is rotational management of field margins with a sub-set of the margins within a farm cut or grazed in May, and the remainder left undisturbed throughout the growing season. While the cut margins would benefit pollinating insects, the undisturbed, unfertilised part would allow an architecturally complex sward to develop for the benefit of Auchenorrhyncha, other invertebrate taxa and ground-nesting birds. The two management regimes for the field margins would be rotated to avoid scrub development. Furthermore the dominance of the grasses in the existing field margins, as in our study, would also help to suppress problematic 
weeds such as Cirsium arvense L. Successful uptake of extensively managed field margins in intensive livestock areas through agri-environment schemes will depend on supplying farmers and other land managers with clear nature conservation objectives and advice on how to achieve these in a cost effective way. The practicalities of the intended management will vary between farms. For example, whilst management of margins adjacent to grazed fields might be expensive due to the cost of fencing, fields managed purely for silage would require no fencing. If this is achieved, then novel grassland field margin management practices could deliver widespread benefits to Auchenorrhyncha and other important components of grassland biodiversity.

\section{Acknowledgements}

This work was conducted as part of the Defra-funded project 'Potential for Enhancing Biodiversity in Intensive Livestock Farms' (BD1444). Thanks to Anne Parkinson and Roger Smith from Rothamsted Research, North Wyke, Alan Stewart for assistance with identification, the research assistants involved in the fieldwork and the farmers for their cooperation.

\section{References}

Andrzejewska, L., 1976. The effect of mineral fertilization of a meadow on the Auchenorrhyncha (Homoptera) fauna. Polish Ecological Studies 2, 111-127.

Asteraki, E.J., Hart, B.J., Ings, T.C., Manley, W.J., 2004. Factors influencing the plant and invertebrate diversity of arable field margins. Agric. Ecosyst. Environ. 102, 219-231. 
Atkinson, P.W., Fuller, R.J., Vickery, J.A., Conway, G.J., Tallowin, J.R.B., Smith, R.E.N., Haysom, K.A., Ings, T.C., Asteraki, E.J., Brown, V.K., 2005. Influence of agricultural management, sward structure and food resources on grassland field use by birds in lowland England. J. Appl. Ecol. 42, 932-942.

Baines, M., Hambler, C., Johnson, P.J., Macdonald, D.W., Smith, H., 1998. The effects of arable field margin management on the abundance and species richness of Araneae (spiders). Ecography 21, 74-86.

Biedermann, R., Achtziger, R., Nicke, H., Stewart, A.J.A., 2005. Conservation of grassland leafhoppers: a brief review. J. Insect Conserv. 9, 229-243.

Brook, A.J., Woodcock, B.A., Sinka, M., Vanbergen, A.J., 2008. Experimental verification of suction sampler capture efficiency in grasslands of differing vegetation height and structure. J. Appl. Ecol. 45, 1357-1363.

Brown, V.K., Gibson, C.W.D., Sterling, P.H., 1990. The mechanisms controlling insect diversity in calcareous grasslands, In: Hillier, S.H., Walton, D.W.H., Wells, D.A. (Eds.), Calcareous Grasslands - Ecology and Management. Bluntisham Books, Bluntisham, pp. 7987.

Defra, 2009. Genrep report PR018 ES Option Uptake - Selected Options Summary. Defra, 2010a. Agricultural Land Use for the United Kingdom.

Defra, 2010b. Entry Level Stewardship Handbook - 3rd Edition. Natural England, UK.

Dennis, P., Young, M.R., Gordon, I.J., 1998. Distribution and abundance of small insects and arachnids in relation to structural heterogeneity of grazed, indigenous grasslands. Ecol. Entomol. 23, 253-264.

Duffey, E., Morris, M.G., Sheail, J., Ward, L.K., Wells, D.A., Wells, T.C.E., 1974. Grassland Ecology and Wildlife Management. Chapman and Hall, London.

Frame, J., 2002. Improved grassland management. Farming Press, Tonbridge, UK. 
Fuller, R.M., 1987. The changing extent and conservation interest of lowland grasslands in England and Wales - A review of grassland surveys 1930-84. Biol. Conserv. 40, 281-300.

Gibson, C.W.D., Hambler, C., Brown, V.K., 1992. Changes in spider (Aranae) assemblages in relation to succession and grazing management. J. Appl. Ecol. 29, 132-142.

Green, B.H., 1990. Agricultural intensification and the loss of habitat, species and amenity in British grasslands - A review of historical change and assessment of future prospects. Grass Forage Sci. 45, 365-372.

Helden, A.J., Anderson, A., Sheridan, H., Purvis, G., 2010. The role of grassland sward islets in the distribution of arthropods in cattle pastures. Insect Conservation and Diversity 3, 291301.

Humbert, J.Y., Ghazoul, J., Walter, T., 2009. Meadow harvesting techniques and their impacts on field fauna. Agric. Ecosyst. Environ. 130, 1-8.

Lawton, J.H., 1983. Plant architecture and the diversity of phytophagous insects. Annual Review of Entomology 28, 23-39.

Marren, P., 2002. Nature Conservation. A review of the conservation of wildlife in Britain 1950-2001. Harper Collins, London, UK.

Meek, B., Loxton, D., Sparks, T., Pywell, R., Pickett, H., Nowakowski, M., 2002. The effect of arable field margin composition on invertebrate biodiversity. Biol. Conserv. 106, 259-271. Morris, M.G., 1971. Differences between invertebrate faunas of grazed and ungrazed chalk grassland .4. Abundance and diversity of Homoptera - Auchenorhyncha. J. Appl. Ecol. 8, 3751.

Morris, M.G., 1973. Effects of seasonal grazing on Heteroptera and Auchenorhyncha (Hemiptera) of chalk grassland. J. Appl. Ecol. 10, 761-780.

Morris, M.G., 1981. Responses of grassland invertebrates to management by cutting .3. Adverse effects on Auchenorhyncha. J. Appl. Ecol. 18, 107-123. 
Morris, M.G., 1990. The effects of management on the invertebrate community of calcareous grassland, In: Hillier, S.H., Walton, D.W.H., Wells, D.A. (Eds.), Calcareous Grasslands Ecology and Management. Bluntisham Books, Bluntisham, UK, pp. 128-133.

Morris, M.G., 2000. The effects of structure and its dynamics on the ecology and conservation of arthropods in British grasslands. Biol. Conserv. 95, 129-142.

Morris, M.G., Lakhani, K.H., 1979. Responses of grassland invertebrates to management by cutting .1. Species-diversity of Hemiptera. J. Appl. Ecol. 16, 77-98.

Morris, M.G., Rispin, W.E., 1987. Abundance and diversity of the Coleopterous fauna of a calcareous grassland under different cutting regimes. J. Appl. Ecol. 24, 451-465.

Nickel, H., Achtziger, R., 2005. Do they ever come back? Responses of leafhopper communities to extensitication of land use. J. Insect Conserv. 9, 319-333.

Nickel, H., Hildebrandt, J., 2003. Auchenorrhyncha communities as indicators of disturbance in grasslands (Insecta, Hemiptera) - a case study from the Elbe flood plains (northern Germany). Agric. Ecosyst. Environ. 98, 183-199.

Nickel, H., Holzinger, W.E., Wachmann, E., 2002. Mitteleuropäische Lebensräume und ihre Zikaden (Insecta: Hemiptera: Auchenorrhyncha). Denisia, 279-328.

Nickel, H., Remane, R., 2002. Artenliste der Zikaden Deutschlands, mit Angabe von Nährpflanzen, Nahrungsbreite, Lebenszyklus, Areal und Gefährdung (Hemiptera, Fulgoromorpha et Cicadomorpha). Beitraege zur Zikadenkunde 5, 27-64.

O'Connor, R.J., Shrubb, M., 1986. Farming and birds. Cambridge University Press.

Potts, S.G., Woodcock, B.A., Roberts, S.P.M., Tscheulin, T., Pilgrim, E.S., Brown, V.K., Tallowin, J.R., 2009. Enhancing pollinator biodiversity in intensive grasslands. J. Appl. Ecol. 46, 369-379.

Prestidge, R.A., 1982. The influence of nitrogenous fertilizer on the grassland Auchenorrhyncha (Homoptera). J. Appl. Ecol. 19, 735-749. 
SAS, 2008. Statistical Analysis System: Version 9.2. SAS Institute, Cary, NC, USA.

Sedlacek, J.D., Barrett, G.W., Shaw, D.R., 1988. Effects of Nutrient Enrichment on the Auchenorrhyncha (Homoptera) in Contrasting Grassland Communities. J. Appl. Ecol. 25, 537-550.

Sheridan, H., Finn, J.A., Culleton, N., O'Donovanc, G., 2008. Plant and invertebrate diversity in grassland field margins. Agric. Ecosyst. Environ. 123, 225-232.

Tallowin, J.R.B., Smith, R.E.N., Goodyear, J., Vickery, J.A., 2005. Spatial and structural uniformity of lowland agricultural grassland in England: a context for low biodiversity. Grass Forage Sci. 60, 225-236.

Vickery, J.A., Tallowin, J.R., Feber, R.E., Asteraki, E.J., Atkinson, P.W., Fuller, R.J., Brown, V.K., 2001. The management of lowland neutral grasslands in Britain: effects of agricultural practices on birds and their food resources. J. Appl. Ecol. 38, 647-664.

Woodcock, B.A., Potts, S.G., Pilgrim, E., Ramsay, A.J., Tscheulin, T., Parkinson, A., Smith, R.E.N., Gundrey, A.L., Brown, V.K., Tallowin, J.R., 2007a. The potential of grass field margin management for enhancing beetle diversity in intensive livestock farms. J. Appl. Ecol. $44,60-69$.

Woodcock, B.A., Potts, S.G., Tscheulin, T., Pilgrim, E., Ramsey, A.J., Harrison-Cripps, J., Brown, V.K., Tallowin, J.R., 2009. Responses of invertebrate trophic level, feeding guild and body size to the management of improved grassland field margins. J. Appl. Ecol. 46, 920929.

Woodcock, B.A., Potts, S.G., Westbury, D.B., Ramsay, A.J., Lambert, M., Harris, S.J., Brown, V.K., 2007b. The importance of sward architectural complexity in structuring predatory and phytophagous invertebrate assemblages. Ecol. Entomol. 32, 302-311. 
Woodcock, B.A., Pywell, R.F., Roy, D.B., Rose, R.J., Bell, D., 2005. Grazing management of calcareous grasslands and its implications for the conservation of beetle communities. Biol. Conserv. 125, 193-202. 


\section{Figure captions}

Fig. 1. Response of Auchenorrhyncha to management treatments from $2003-2005$ (a) abundance (mean numbers per treatment $\pm \mathrm{SE}$ ); (b) species richness (mean number of species per treatment $\pm \mathrm{SE}$ ). Graphs show untransformed data. Full description of the management treatments $1-7$ is given in the text.

Fig. 2. Response of Auchenorrhyncha to categorical environmental variables (a) abundance (mean numbers per treatment $\pm \mathrm{SE})$ following number of cuts $(0=$ no cut, $1=$ one cut, $2=$ two cuts); (b) species richness (mean number of species per treatment \pm SE) following grazing $($ No $=$ no grazing, Yes $=$ grazing$)$. Graphs show untransformed data. Full description of the management treatments 1-7 is given in the text.

Fig. 3. Response of sward architectural complexity to management treatments from $2003-$ 2005 (mean values per treatment \pm SE). Full description of the management treatments 1-7 is given in the text. 
Table 1. Management practices used to establish the seven field margin treatments

\begin{tabular}{|c|c|c|c|c|c|c|c|}
\hline \multirow[b]{2}{*}{ Management } & \multicolumn{7}{|c|}{ Experimental treatments } \\
\hline & 1 & 2 & 3 & 4 & 5 & 6 & 7 \\
\hline Fertilizer application & $*$ & & $*$ & $*$ & & & \\
\hline Silage cut $(5 \mathrm{~cm})$ in May & $*$ & $*$ & & $*$ & & & \\
\hline Silage cut $(10 \mathrm{~cm})$ in May & & & $*$ & & $*$ & & \\
\hline Silage cut $(5 \mathrm{~cm})$ in July & $*$ & $*$ & & $*$ & & & \\
\hline Silage cut $(10 \mathrm{~cm})$ in July & & & $*$ & & & & \\
\hline Hay cut in July & & & & & & $*$ & \\
\hline Aftermath grazing & $*$ & $*$ & $*$ & & & & \\
\hline
\end{tabular}


Table 2. Summary of Auchenorrhyncha abundance and species richness to margin management treatments (Model 1), and the categorical environmental variables (Model 2)

\begin{tabular}{|c|c|c|c|c|c|}
\hline Model & & Total Auchenorrhyncha & Monophagous species & Oligophagous species & Polyphagous species \\
\hline \multirow[t]{2}{*}{1} & Abundance $\left(\log _{\mathrm{e}} n+1\right)$ & $\begin{array}{l}\text { Treat: } F_{6,25.2}=6.92 * * * \\
\text { Year: } F_{2,49.9}=21.54 * * * \\
\text { Treat } \times \text { year: NS } \\
\text { AIC: } 105.5\end{array}$ & $\begin{array}{l}\text { Treat: } F_{6,23}=4.45^{* *} \\
\text { Year: } F_{2,49.1}=43.14 * * * \\
\text { Treat } \times \text { year: NS } \\
\text { AIC: } 249.3\end{array}$ & $\begin{array}{l}\text { Treat: } F_{6,31.9}=12.68^{* * *} \\
\text { Year: } F_{2,47.7}=22.36^{* * *} \\
\text { Treat } \times \text { year: NS } \\
\text { AIC: } 122.3\end{array}$ & $\begin{array}{l}\text { Treat: } F_{6,25.9}=2.97 * \\
\text { Year: } F_{2,52.7}=53.10^{* * *} \\
\text { Treat } \times \text { year: NS } \\
\text { AIC: } 147.5\end{array}$ \\
\hline & Species Richness $\left(\log _{\mathrm{e}} n+1\right)$ & $\begin{array}{l}\text { Treat: } F_{6,22.3}=3.45^{*} \\
\text { Year: } F_{2,47}=38.31^{* * *} \\
\text { Treat } \times \text { year: NS } \\
\text { AIC: }-56.9\end{array}$ & $\begin{array}{l}\text { Treat: NS } \\
\text { Year: } F_{6,49.4}=56.78^{* * *} \\
\text { Treat } \times \text { year: NS } \\
\text { AIC: } 57.0\end{array}$ & $\begin{array}{l}\text { Treat: } F_{6,33.5}=4.59 * * \\
\text { Year: } F_{2,52.4}=10.76 * * * \\
\text { Treat } \times \text { year: NS } \\
\text { AIC: }-66.6\end{array}$ & $\begin{array}{l}\text { Treat: NS } \\
\text { Year: } F_{2,49.1}=14.46^{* * *} \\
\text { Treat } \times \text { year: NS } \\
\text { AIC: }-17.2\end{array}$ \\
\hline \multirow[t]{2}{*}{2} & Abundance $\left(\log _{\mathrm{e}} n+1\right)$ & $\begin{array}{l}\text { Year: } F_{2,50.3}=21.14 * * * \\
\text { Grazed: NS } \\
\text { Cutting no.: } F_{2,28.7}=17.19 * * * \\
\text { N treat: NS } \\
\text { Grazed } \times \text { year: NS } \\
\text { Cutting no. } \times \text { year: NS } \\
\text { N treat } \times \text { year: NS } \\
\text { AIC: } 102.9\end{array}$ & $\begin{array}{l}\text { Year: } F_{2,49.5}=42.96^{* * *} \\
\text { Grazed: } F_{1,25.9}=9.34 * * \\
\text { Cutting no.: } F_{2,25.9}=9.43^{* * *} \\
\mathrm{~N} \text { treat: NS } \\
\text { Grazed } \times \text { year: NS } \\
\text { Cutting no. } \times \text { year: NS } \\
\text { N treat } \times \text { year: NS } \\
\text { AIC: } 251.9\end{array}$ & $\begin{array}{l}\text { Year: } F_{2,47.2}=28.30 * * * \\
\text { Grazed: NS } \\
\text { Cutting no.: } F_{2,33.1}=11.75^{* * *} \\
\text { N treat: NS } \\
\text { Grazed } \times \text { year: NS } \\
\text { Cutting no. } \times \text { year: NS } \\
\text { N treat } \times \text { year: } F_{2,47.2}=5.07 * \\
\text { AIC: } 115.4\end{array}$ & $\begin{array}{l}\text { Year: } F_{2,54.1}=55.39 * * * \\
\text { Grazed: NS } \\
\text { Cutting no.: } F_{2,30.8}=8.94 * * * \\
\text { N treat: NS } \\
\text { Grazed } \times \text { year: NS } \\
\text { Cutting no. } \times \text { year: NS } \\
\text { N treat } \times \text { year: NS } \\
\text { AIC: } 142.5\end{array}$ \\
\hline & Species Richness $\left(\log _{\mathrm{e}} n+1\right)$ & $\begin{array}{l}\text { Year: } F_{2,48.0}=37.01 * * * \\
\text { Grazed: } F_{1,28.2}=22.12 * * * \\
\text { Cutting no.: NS } \\
\mathrm{N} \text { treat: NS } \\
\text { Grazed } \times \text { year: NS } \\
\text { Cutting no. } \times \text { year: NS } \\
\mathrm{N} \text { treat } \times \text { year: NS } \\
\text { AIC: }-77.2\end{array}$ & $\begin{array}{l}\text { Year: } F_{2,50.4}=58.15^{* * *} \\
\text { Grazed: } F_{1,26.8}=6.71^{*} \\
\text { Cutting no.: } F_{2,26.8}=3.69 * \\
\text { N treat: NS } \\
\text { Grazed } \times \text { year: NS } \\
\text { Cutting no. } \times \text { year: NS } \\
\text { N treat } \times \text { year: NS } \\
\text { AIC: } 54.2\end{array}$ & $\begin{array}{l}\text { Year: } F_{2,54.2}=10.98 * * * \\
\text { Grazed: } F_{1,39.7}=28.70 * * * \\
\text { Cutting no.: NS } \\
\text { N treat: NS } \\
\text { Grazed } \times \text { year: NS } \\
\text { Cutting no. } \times \text { year: NS } \\
\text { N treat } \times \text { year: NS } \\
\text { AIC: }-88.7\end{array}$ & $\begin{array}{l}\text { Year: } F_{2,49.1}=14.46^{* * *} \\
\text { Grazed: NS } \\
\text { Cutting no.: NS } \\
\text { N treat: NS } \\
\text { Grazed } \times \text { year: NS } \\
\text { Cutting no. } \times \text { year: NS } \\
\text { N treat } \times \text { year: NS } \\
\text { AIC: }-17.2\end{array}$ \\
\hline
\end{tabular}

NS, $P>0.05 ; * P<0.05 ; * * P<0.01 ; * * * P<0.001$. Coding for environmental variable is given in the Methods. Non-significant terms removed from models by stepwise deletion. 
Table 3. Summary of Auchenorrhyncha abundance and species richness to the continuous environmental variables (Model 3)

\begin{tabular}{|c|c|c|c|c|c|}
\hline Model & & Total Auchenorrhyncha & Monophagous species & Oligophagous species & Polyphagous species \\
\hline 3 & Abundance $\left(\log _{\mathrm{e}} n+1\right)$ & $\begin{array}{l}\text { Year: } F_{2,54.1}=20.1 * * * \\
\text { Sward: NS } \\
\text { Grass: NS } \\
\text { Forb: NS } \\
\text { Sward } \times \text { year: NS } \\
\text { Grass } \times \text { year: NS } \\
\text { Forb } \times \text { year: NS } \\
\text { AIC: } 119.9\end{array}$ & $\begin{array}{l}\text { Year: } F_{2,51.8}=18.44 * * * \\
\text { Sward: NS } \\
\text { Grass: NS } \\
\text { Forb: NS } \\
\text { Sward } \times \text { year: NS } \\
\text { Grass } \times \text { year: } F_{2,52.7}=6.79 * * \\
\text { Forb } \times \text { year: NS } \\
\text { AIC: } 263.8\end{array}$ & $\begin{array}{l}\text { Year: NS } \\
\text { Sward: NS } \\
\text { Grass: NS } \\
\text { Forb: NS } \\
\text { Sward } \times \text { year: NS } \\
\text { Grass } \times \text { year: NS } \\
\text { Forb } \times \text { year: } F_{2,63.5}=3.68 * \\
\text { AIC: } 113.7\end{array}$ & $\begin{array}{l}\text { Year: } F_{2,56.0}=47.72 * * * \\
\text { Sward: NS } \\
\text { Grass: NS } \\
\text { Forb: NS } \\
\text { Sward } \times \text { year: NS } \\
\text { Grass } \times \text { year: NS } \\
\text { Forb } \times \text { year: NS } \\
\text { AIC: } 155.0\end{array}$ \\
\hline & Species Richness $\left(\log _{\mathrm{e}} n+1\right)$ & $\begin{array}{l}\text { Year: } F_{2,70.9}=15.14 * * * \\
\text { Sward: NS } \\
\text { Grass: } F_{1,64.0}=14.39 * * * \\
\text { Forb: NS } \\
\text { Sward } \times \text { year: NS } \\
\text { Grass } \times \text { year: NS } \\
\text { Forb } \times \text { year: } F_{2,72.8}=5.73 * * \\
\text { AIC: }-58.8\end{array}$ & $\begin{array}{l}\text { Year: } F_{2,62.0}=15.09 * * * \\
\text { Sward: NS } \\
\text { Grass: } F_{1,67.8}=9.39 * * \\
\text { Forb: NS } \\
\text { Sward } \times \text { year: NS } \\
\text { Grass } \times \text { year: } F_{2,63.3}=4.20 * \\
\text { Forb } \times \text { year: NS } \\
\text { AIC: } 55.6\end{array}$ & $\begin{array}{l}\text { Year: NS } \\
\text { Sward: } F_{1,39.0}=11.13^{* *} \\
\text { Grass: NS } \\
\text { Forb: NS } \\
\text { Sward } \times \text { year: } F_{2,70.9}=4.25^{*} \\
\text { Grass } \times \text { year: NS } \\
\text { Forb } \times \text { year: NS } \\
\text { AIC: }-81.8\end{array}$ & $\begin{array}{l}\text { Year: } F_{2,70.8}=8.65^{* * *} \\
\text { Sward: NS } \\
\text { Grass: } F_{1,57.2}=10.03 * * \\
\text { Forb: NS } \\
\text { Sward } \times \text { year: NS } \\
\text { Grass } \times \text { year: NS } \\
\text { Forb } \times \text { year: } F_{2,72.6}=6.48^{* *} \\
\text { AIC: }-11.8\end{array}$ \\
\hline
\end{tabular}

NS, $P>0.05 ; * P<0.05 ; * * P<0.01 ; * * * P<0.001$. Coding for environmental variable is given in the Methods. Non-significant terms removed from models by stepwise
deletion. 